\title{
Indoor and outdoor pollution in cloth dyeing: examples from textile studios in Nigeria tertiary institutions
}

\author{
D. O. Mákindé, E. T. Ìjísakin \& Y. O. Ìjísakin \\ Department of Fine \& Applied Arts, Obáfémi Awólówò University, \\ Ile-Ife, Nigeria
}

\begin{abstract}
Cloth dyeing has been confirmed to be a major cause of pollution because the dyes used contain some substances which are injurious to humans and their environment. This paper examined cloth dyeing activities in some selected art institutions in Nigeria. The study made use of 50 systematically selected students from the three levels of tertiary institutions in Nigeria. All the institutions surveyed lack adequate studio spaces, ventilation, personal protective equipment, and dye waste drainage required for productive and hazard-free cloth dyeing. It was also discovered that most synthetic dyes used have no user guides. This paper concluded that more dyes need to be studied for hazard identification and prevention. Adequate provision for studio space and amenities should be vigorously pursued and governments should monitor manufacturers of synthetic dyes and chemicals to reduce or eliminate health risks in cloth dyeing.

Keywords: hazards, synthetic dyes, cloth dyeing, pollution, art studio, chemicals. tertiary institutions, toxic.
\end{abstract}

\section{Introduction}

Cloth dyeing is an age long craft tradition among the people of Nigeria [1]. Though it has an obscure and controversial origin, its practice in Nigeria has spanned several decades [2]. In the ancient times traditional dyeing relied heavily on locally sourced materials (dyes and mordant) and indigenous technology [3]. From 1930 onwards the use of synthetic dyes and chemicals (manufactured) replaced the natural dyes (indigo) which are considered slow, laborious and time consuming [4]. Hence, the use of synthetic dyes has continued at cottage and 
institutional levels in Nigeria without due consideration for their health implications [3]. This confirms the possibility of health risks among textile students in Nigeria. At this juncture it is important to note that, adequate studies have not been carried out on the indoor and outdoor pollution from cloth dyeing activities among students of higher institutions in Nigeria. Attempts to identify causes or forms of these hazards on human health have also not been adequately documented. This study is therefore focused on three selected tertiary art institutions (college of education, polytechnic and university) in Nigeria.

An issue of environmental pollution, hazards and health risks, attributed to cloth dyeing activities has not been adequately studied by textile artists in Nigeria [3]. There is documented evidence that all dyes and chemicals are corrosive, toxic and potentially injurious to man [4]. In spite of this, cloth dyeing activities have continued to grow at cottage and institutional levels [5]. Cloth dyeing is a process of cloth decoration for aesthetic and functional purposes [5]. This process requires the application of various ingredients (dyes and chemicals) at a point which may require dissolving, dilutions, or heating [6]. In the process, fumes and gases are produced which if inhaled could cause respiratory tract problems or burns when in contact with the body [4].

This study attempts to provide answers to the following questions: What percentage of dyes are tested for hazards or labeled? What is the level of hazard education attained by students? Are the studios adequate in space, amenities and ventilation? Do the dye containers used by the students bear labeled information regarding their uses and hazards? This study is important for a number of reasons: First, dyers will be conscious of the implication of cloth dyeing for their health. Second, it will help dye manufacturers identify toxic elements in synthetic dyes and chemicals. Finally, it will help dye manufacturers provide useful information on the properties and contents of the dyes.

\section{Issues in cloth dyeing}

Many books, (hard copy and electronic) are available on traditional and contemporary dyeing techniques. However, there is dearth of information on health risks and hazards associated with cloth dyeing. A study on outdoor pollution among the Ėgbá dyers in 2001 established that materials used in cloth dyeing pose a threat to the dyers and their environment [3]. The study confirmed that both the state and local government are ignorant of the risks associated with cloth dyeing. The study concluded that environmental sanitation education among the Ėgbá dyers is very poor [3]. The Occupational Safety and Health Administration (OSHA) reports observe that the process of cloth dyeing is almost entirely chemical because dyes are made up of synthetic chemicals which are hazardous in nature [6]. The dyes contain highly toxic impurities some of which host bacteria which could cause cancer. Chemists mentioned that chemicals (caustic soda and hydrous) used in the preparation of dyes are injurious to the human kidney [7].

It has also been shown that synthetic dyes and chemicals contain life threatening substances which, if inhaled, could cause serious sneezing, coughing, feelings of suffocation and burns in cases of body contact [8]. The cloths used in 
the process of dyeing may contain a residue of chemicals transferred from the insecticides or herbicides used by manufacturers on the fiber which often remain untreated up to the time it gets to the dyer. A summary of health hazards posed by the materials used by the artists which affect the lungs, blood, and the nervous system, have earlier been documented [9].

Inadequate or non-labeling of containers (dyes and chemicals) often cause hazards to dyers. Most synthetic dyes imported into Nigeria have no labeled or other information on their preparation, use and health implications. In essence, hazards may be created when two incompatible dyes and chemicals are mixed together.

Over exposure to dyes and chemicals use by textile students in their normal school assignments and part time dyeing activities is also responsible for the cause of perennial cough and asthma that are commonly reported among textile students [10]. The process of dye and chemical preparation often lead to heat generation and gas emissions which often constitute serious health risks most especially when they are inhaled [11]. When dye splashes on the body, it burns, causing irritation and nervousness. Waste water generated through dyeing activities must be carefully disposed of at a designated area to avoid any form of health risk. To achieve the above, an ideal textile studio is supposed to be in multiples of at least eight unitrooms consisting of surface design, dyeing, dark-room, printing and fashion sections. Others include, weaving, embroidery, sewing, computer laboratory and lecture rooms which none of the art institutions in Nigeria have been able to provide.

\section{Study area}

The study area is the selected art institutions in six southwestern states of Nigeria predominantly dominated by Yoruba speaking people. These art institutions are grouped into three levels of tertiary institutions: polytechnics, colleges of education and universities. These are further classified as federal and state owned institutions. A preliminary survey shows that there are 20 art institutions (tertiary) in the southwestern part of Nigeria; ten colleges of education, four polytechnics and six universities. Out of this number, six belong to the state governments while others belong to the federal government.

\section{Methodology}

The data for the study were obtained from students in the three categories of institutions. The institutions were selected to reflect the three forms of higher institutions. Fifty percent of schools were selected in each category: five colleges of education two polytechnics and three universities were studied from 10, 4 and 6 respectively. Their selection was based on a random method without replacement. Five textile students were sampled from each of the schools selected. With the above methodology, a total of 25,10 , and 15 students were sampled respectively, in the colleges of education, the polytechnics and the universities. Information obtained from students includes: art studio situations in 
their institutions, their knowledge of studio ethics, hazard communication system, waste water drainage and use of personal protective equipment.

\section{Research findings}

The study established that students do not use the self-protective devices probably because of the functions of these personal protective equipments needed to protect them from long or short term studio hazards. Confirming this is the fact that $80 \%, 86 \%$ and $58 \%$ of the population have suffered from optical diseases, cough and catarrh in the three levels of institutions respectively. It can therefore, be concluded that, students do not understanding how dyes and chemicals could cause hazards to them when they are inhaled or when they have contact with their bodies in the course of cloth dyeing.

Students' responses to questions on studio requirements and what is available in the institutions confirmed that they are knowledgeable about what and how an ideal studio should be. The study concludes that none of the three levels of tertiary institutions have the basic studio requirements in terms of size, number and provision for adequate ventilation and regular water supply. Unless the above problem is addressed, the problem of overcrowding may be a permanent feature in Nigeria tertiary institutions

It is also more important to protect oneself against hazards during the dyeing exercise [10]. Therefore, the use of personal protective equipment (hand-gloves, nose and face shield, goggle, apron and shoes) is essential to hazard free cloth dyeing activities. Nonetheless, the student's responses to these questions confirmed that an insignificant percentage (10\%) used these facilities during the dyeing process. Invariably, textile students across the three levels of institutions are at great risk of short or long term hazard effects on the students.

As summarized in table 1, the study established that, only $20 \%$ of the students in all the institutions surveyed use dyes that carry information on their containers. Studio materials especially, dyes and chemicals are supposed to be labeled to avoid wrongful identification and usage. The study confirms that $10 \%$ of the students in all the institutions use materials that are labeled. In addition, lectures on hazard identification and prevention including studio ethics were not given to students as required.

As summarized in table 2, all the tertiary institutions studied for waste dye disposal are disabled in terms of waste water management. Very high percentages $(80 \%)$ of textile students in all the institutions surveyed have no particular way of disposing of their waste dye solution. The study established that all institutions dispose of their dye waste solution just anywhere outside the studio without due consideration for the fauna and the soil. Indiscriminate disposal of contaminated dye waste causes water (well water) poisoning, when it is very close to the studio as found in one of the schools studied. In addition, it increases the acidic level of the soil thereby causing soil infertility [12]. Although this may not have a short term effect on the environment and users, it is dangerous when considered in terms of its long term effects. The study also confirms that none of the institutions studied have timers or devices to control heat generation in the process of melting bee or paraffin wax for resist dyeing. 
Table 1: $\quad$ Percentage of students with knowledge of hazard communication.

\begin{tabular}{|c|c|c|c|c|}
\hline $\begin{array}{c}\text { Hazard } \\
\text { communication. }\end{array}$ & College & Polytechnic & University & $\begin{array}{c}\text { All } \\
\text { schools }\end{array}$ \\
\hline $\begin{array}{c}\text { Labels on dye } \\
\text { container. }\end{array}$ & 20 & 30 & 13.6 & 20 \\
\hline Instructions for users & 20 & 20 & 6.6 & 16 \\
\hline Fire-extinguisher. & - & - & 13.6 & 4 \\
\hline Sealed dye container. & 28 & 30 & 6.6 & 12 \\
\hline $\begin{array}{c}\text { Labeling of studio } \\
\text { materials. }\end{array}$ & 14 & 20 & 13.6 & 10 \\
\hline $\begin{array}{c}\text { Lectures on hazard } \\
\text { identification/ } \\
\text { prevention? }\end{array}$ & 12 & 30 & 13.6 & 16 \\
\hline Studio ethics. & 8 & 20 & 30 & 14 \\
\hline Total. & 25 & 10 & 15 & 50 \\
\hline \multicolumn{2}{c}{} & & & \\
\hline
\end{tabular}

Table 2: $\quad$ Proportion (\%) of students who utilize different methods of dye waste disposal.

\begin{tabular}{|c|c|c|c|c|}
\hline waste disposal avenues. & College & Polytechnic & University & $\begin{array}{c}\text { All } \\
\text { Schools }\end{array}$ \\
\hline Dug pit & 20 & 30 & 20 & 20 \\
\hline Open gutter & 80 & - & 10 & 10 \\
\hline Anywhere & 80 & 80 & 80 & 80 \\
\hline Outside the studio & 24 & 60 & 32 & 32 \\
\hline Container & - & 20 & 8 & 8 \\
\hline Water closet & - & 10 & - & 2 \\
\hline Total & 25 & 10 & 15 & 50 \\
\hline
\end{tabular}

Table 3: Percentage of students with different methods of dye and chemical preparation.

\begin{tabular}{|c|c|c|c|c|}
\hline Dye and chemical preparation & College & Poly & Univ & $\begin{array}{c}\text { All } \\
\text { schools }\end{array}$ \\
\hline Adding chemical into dye solution. & 20 & 30 & 20 & 20 \\
\hline Pouring dye solution into chemical. & 80 & 70 & 53.3 & 70 \\
\hline Mix them dry with chemical later. & - & 10 & 6.6 & 4 \\
\hline Melt wax on stove. & 60 & 80 & 73.3 & 68 \\
\hline Melt wax on electric stove. & 32 & 60 & 80 & 52 \\
\hline Measure dyes and before use & 12 & 20 & 26.6 & 14 \\
\hline Use of timer & 16 & 30 & 26.6 & 18 \\
\hline Use of powdered dyes.. & 40 & 60 & 73.3 & 54 \\
\hline Total. & 25 & 10 & 15 & 50 \\
\hline
\end{tabular}


The tables above show the students' response to dye and chemical preparation, the techniques of dyeing and the procedure for doing it. It can be deduced from the tables that students do not actually use proper techniques of dye and chemical preparation which experts say is best as liquid or paste [12]. As indicated in table 3 , about $54 \%$ of the total number of students use powdered dyes which have been suggested to expose dyers to respiratory problems when removed from the plastic container [4]. According to experts, it could easily escape through the nose to the lung thereby causing respiratory ulcers. This study however established that the equipment for measuring dyes before use is highly necessary to avoid abuse which may lead to health risks. Only $14 \%$ of all the students from the three levels of institutions measure dyes and chemicals before use, using self-device measures. The study confirmed that, such standard electronic equipment is not available in any of the institutions visited by this team.

The use of electronic equipment to determine the quantity of dyes and chemicals required before dyeing is very important to avoid violent and exothermic reactions from certain heat reactive chemicals (when these dyes and chemicals are mixed with water above the recommended mixing temperature proportion or when overheated). Sodium hydroxide (caustic soda) and sodium hydrosulphide (hydro) are good examples. The reaction may be violent when excessive amounts of such chemicals are used or when the chemical is added more quickly than the time necessary for it to dissolve. The absence of a timer, a measuring cylinder and a temperature gauge may lead to serious health hazards such as respiratory problems. In addition, over-heating of wax, due to lack of temperature measuring equipment such as timers which could help to control fumes and gases produced in the process may also cause temporary pollution in the studios. These fumes and gases when inhaled cause respiratory tract blockage which, according to [4] has long-term effects on the dyer and his/her neighbour. Arising from the result on the table it is evident that respiratory problems may be rampant in the three levels of institutions due to over crowdedness in their studios.

Table 4: $\quad$ Students with reported health cases in the last 3 years.

\begin{tabular}{|c|c|c|c|c|}
\hline $\begin{array}{c}\text { Identified health } \\
\text { problems }\end{array}$ & $\begin{array}{c}\text { College of } \\
\text { Education }\end{array}$ & Polytechnic & University & $\begin{array}{c}\text { All } \\
\text { schools }\end{array}$ \\
\hline Fever & 72 & 80 & 17.3 & 48 \\
\hline Irritation & 44 & 70 & 12 & 54 \\
\hline Burns & 24 & 80 & 20 & 34 \\
\hline Asthma & 08 & 20 & 26.6 & 16 \\
\hline Optical problem & 84 & 70 & 80 & 80 \\
\hline Cough & 92 & 70 & 17.3 & 86 \\
\hline Catarrh & 72 & 50 & 40 & 58 \\
\hline Others & 8 & 30 & 33.3 & 20 \\
\hline Total & 25 & 10 & 15 & 50 \\
\hline
\end{tabular}


Table 4 above summarizes the students' health experiences influenced by their studio activities .It is observable from table 4 that only $72 \%, 50 \%, 40 \%$, respectively, of the students from the three levels of institutions have been treated for symptoms of catarrh while $58 \%$ of the students in all the institutions were treated for the same in the last three years. This may be due to a lack of personal safety equipment (nose guards and face masks and others) or a refusal to use the equipment. Studies have also confirmed that the process of cloth dyeing requires the addition of various ingredients (dyes and chemicals) prepared manually. The preparation of these dyes and chemicals together produce violent chemical reactions accompanied by the release of fumes, gas, heat and sometimes spillage on the floor or body of the dyer. The study suggests that the symptoms and hazards listed in the table are due to non compliance with the precautionary studio measures, such as the use of personal protective equipment at all times.

\section{Conclusion}

This study established that, studio space is grossly inadequate in all the three levels of institutions studied. The peculiarity of textile arts and design which includes cloth dyeing requires the use of multiple studios with at least eight unit rooms to contain the following surface design studio, dye kitchen, coating and exposing room, print studio, classroom, batik room, sewing machine, weaving and dyeing studios. Due to inadequate studio space, about $75 \%$ of the students may be running the risk of short or long term hazards which are likely to be caused by overcrowding in the use of studio while the remaining $25 \%$ may run risk of lung related problems, burns, asthma, cough and respiratory tract diseases, including deadly cancer.

This study confirms that only about $10 \%$ of the dyes used were labeled, which means, students are susceptible to health risks especially when they make the mistake of mixing two incompatible chemicals or dyes together. The labeling of dyes and chemical containers, including other studio materials, is no doubt important to reduce health risks. Over exposure to dye and chemical use constitutes a major source of risks among student dyers. This can however be controlled through the use of personal protective equipment which must be enforced. While some students are engaged in batik assignments which involve the melting of wax, others may be involved in cloth dyeing, dewaxing or printing activities using just one studio room. This situation may lead to over-exposure of students to multiple hazards. The consequence could be short or long-term health risks. This study observes and recommends that, for the students' health to be preserved; more studios have to be built in the three levels of institutions. To reduce health risks generated by cloth dyeing, health and safety manuals with very good illustrations should be produced in large quantities by experts for distribution to prospective dyers or buyers. Students should also be given regular health maintenance lectures which should be tested, scored and enforced. The studios need natural ventilation and local exhaust channels for gas escape to sustain a health risk free studio environment. Finally, dyes and chemical waste 
disposal system should be put in place. It is inevitable if our students and environment are going to be protected from hazards associated with cloth dyeing. It is important at this juncture, to seek the assistance of National Drug Law Enforcement Agencies (NAFDAC) to identify, control and approve the importation of hazard-free dyes and chemicals to the Nigeria market. The above no doubt will ensure hazard-free cloth dyeing.

\section{References}

[1] Lycha P., Àdìre: Resist dyed cloths of the Yoruba. An exhibition brochure of the National Museum of African Art 1977.

[2] Ògúntònà. T., Basic Textiles; Design concepts and methods. Institute of Education, A.B.U. Zaria. 1986

[3] Ògúndúyílé, S.R., Cottage dyeing industry and environmental hazards created by the use of commercial dyes and chemicals. J.A.I. pg. 105-112. 2001.

[4] Karlen P. H., chemicals can be dangerous to your Art "Art week vol. 17 (August, 1986)

[5] Makinde, D.O., 'Survival of Àdìre' (local Textiles) in Nigeria contemporary Textile industry. Edit. Aremu, P.S.O., et al. O.A.U. Ile-Ife. 2005

[6] Stavrondis. C., Health and safety: Hazard communication - your 'Right to know'. Vol. 12, Number 2, OSHA publishers May, 1990

[7] Katz, M. I., can making Art be Hazardous to your health. Art News, v. 80 4, p 68-76. 1981

[8] Sweetman .D., Art Hazards in Health and safety magazines, Historic Textile Studios, Lynn Lanchester, Gorges. 1996.

[9] Rossol. M,, Managing Health and safety in Design Studio. 2002

[10] Saitzyk, S., Art Hardware: The Definitive guide to artists Materials. Art News v.87 Dec. 1987

[11] Bíódún, N., Dyes from plant: their extraction and application to textiles. Tide publishing house, Lagos, Nigeria.1995.

[12] Okundaye, N., Àdìre textile processing in ARTmosphore a publication of national Gallery of Art, Nigeria no.2. 2008. 